Arab Univ. J. Agric. Sci., Ain Shams Univ., Cairo, 14(1), 265-280, 2006

\title{
ESTIMATES OF GENETIC COMPONENTS, PREDICTION AND GENETIC CORRELATION IN WHEAT (TRITICUM AESTIVUM,L.) USING NORTH CAROLINA DESIGN III \\ [17]
}

\author{
Salama $^{1}$, S.M.; S.A. Awaad ${ }^{1}$ and Manal M. Salem ${ }^{1}$
}

\begin{abstract}
North Carolina Design III was used to estimate gene effects in bread wheat crosses. Twelve Egyptian bread wheat genotypes i.e. Sakha 69, Sakha 8, Gemmeiza 1, Gemmeiza 3, Gemmeiza 7, Giza 160, , Giza 162, Giza 164, Giza 165, Sids 1, Sids 3 and Sids 4, each was crossed back to testers, high performing (Gemmeiza 9) and low performing parent (Sakha 92) during three winter successive seasons i.e. 2002/2003, 2003/2004 and 2004/2005, to study; heading date (days) plant height $(\mathrm{cm})$, flag leaf length $(\mathrm{cm})$ flag leaf width $(\mathrm{cm})$, flag leaf area $(\mathrm{cm})^{2}$, extrusion length $(\mathrm{cm})$, number of spikelets/spike, spike grain weight (g.), number of spikes/plant, number of grains/spike, 1000-grain weight (g.) and grain yield/plant (g.) characters. Results indicated that epistasis played great role in the inheritance of all studied characters except number of spikes/plant. Additive(D)and dominance $(\mathrm{H})$ genetic variances were significant in all studied characters except number of spikes/plant and number of grains/spike. The additive genetic variance was more than dominance for heading date, plant height, flag leaf length, flag leaf width, extrusion length, spike length and 1000- grain weight. The ratio of (H./D) ${ }^{0.5}$ was less than one for these characters but for the remaining characters the dominance genetic variance was more than additive. The values of $(F)$ indicated that dominance was unidirectional for flag leaf length and flag leaf area, whereas it was ambidirectional for the remaining characters Prediction results revealed that it could be possible to derive reasonable proportion of new recombinants which are falling out side parental range for heading date, flag leaf length, flag leaf width, spike length, number of spikelets/spike, number of spikes/plant, 1000- grain weight and grain yield/plant. Genetic correlation indicated that additive, dominance and epistasis gene effects controlling grain yield/plant and spike grain weight, number of spikes/plant, number of grains/spike, 1000- grain weight, were signifant, suggesting common genetic pool or pleiotropy. Thus, selection based on additive genetic correlation indicated that indirect selection via, spike grain weight, number of spikes/plant, number of grains/spike and 1000- grain weight would be effective and enhance its importance as selection criteria .
\end{abstract}

1- Central Laboratory for Design and Statistical Analysis Research, Agricultural Research Center, Giza, Egypt

(Received September 18, 2005)

(Accepted October 26, 2005) 
Keywords:, Gene-effects, High performing and low performing, Heading date, Plant height $(\mathrm{cm})$, Flag leaf length and width $(\mathrm{cm})$, Flag leaf area $(\mathrm{cm})^{2}$, Extrusion length $(\mathrm{cm})$, Number of spikelets/spike, Spike grain weight (g), Number of spikes/plant, Number of grains/spike, 1000-grain weight $(\mathrm{g})$ and grain yield/plant $(\mathrm{g})$ characters

\section{INTRODUCTION}

In any breeding programme the standpoint is to determine mode of gene action controlling types of gene effects to help the breeder for rightful decision making about breeding methodology to be adopted. The North Carolina Design III (N. C. D.) is considered the one which have been developed to provide information on specific genotypes. Such information could be helpful for better choice promising genotypes which should be included in breeding programme of all the genetic procedures based on second degree statistics which are used to estimate the components of continuous variations. North Carolina Design III (Comstock and Robinson 1952) and its modified version triple test cross (Kearsey and Jinks, 1968) had the least assumptions (retracted), and therefore is more widely applicable for investigating materials of various kinds. In addition allowing detection of epistasis and unambiguous estimation of additive as well as dominance components if epistasis is absent.

Many researchers used triple test cross and North Carolina Design in wheat i.e. Singh et al 1988; Singh (1989); Nanda et al (1990) and Eissa (1994 a) to estimate the dominance, additive and epistasis components of genetic variation for morphological characters and indicated the importance of these components in the genetic variance of wheat yield and yield characters while, Eissa (1994b) and (1994c) indicate that the epistatic gene effects played an important role in genetic system for yield characters of wheat. North Carolina Design III (N.C.D.III) was studied by Al-Kaddoussi (1997) for several characters in Egyptian bread wheat genotypes. and found that epistasis played a great role in the inheritance of all characters, except extrusion length, spike length, spike grain weight and number of spikes/plant. Many researches on genetic variance of wheat were applied by Pawar et al (1994), Katiyar and Ziauddin (1996), Salama (1998), Salama (2000 a), Salama (2000 b) and Salama (2002) to study the genetic component and inheritance of yield in wheat.

\section{MATERIAL AND METHODS}

The present study was carried out at Tag El-Ezz Research Station Dakahlia Governorate during three winter successive growing seasons i.e. 2002/ 2003, 2003/2004 and 2004/ 2005 using fourteen wheat genotypes, namly; Sakha69, Sakha 92, Sakha 8, Gemmeiza 1, Gemmeiza 3, Gemmeiza 7, Gemmiza 9, Giza 160, Giza 162, Giza 164, Giza 165, Sids 1, Sids 3 and sids4 The genotypes names and pedigree are shown in Table (1). The fourteen wheat genotypes were evaluated for the studied characters during 2002/2003 to obtain information about the highest and the lowest performing wheat genotypes to 
Table 1. Pedigree of the studied parental wheat genotypes .

\begin{tabular}{|cll|}
\hline $\begin{array}{c}\text { Serial } \\
\text { number }\end{array}$ & \multicolumn{1}{c|}{ Genotype } & \multicolumn{1}{c|}{ Pedigree } \\
\hline 1 & Sakha 69 & Inia/RL 4220//72/Kr " s" \\
2 & Sakha 8 & Indus/Norteno "s"//PK 3418 \\
3 & Gimmeiza 1 & Maga 74 "s"/oN // 1160. 147 / 3 / B6 / Gallo//4/Chat "s" \\
4 & Gimmeiza 3 & B6/7c*2//y50E/Kal//*3 x Sakha 8/4 RR V/ww 15/3/Bj \\
& & "s" // on * 3/BON. \\
5 & Gimmeiza 7 & CMM 74A.630/Sx//seri 82/3/Agent \\
6 & Giza 160 & Chenab70/Giza 155. \\
7 & Giza 162 & Vcm //CnO 67 "s"/7c/3/KalBb. \\
8 & Giza 164 & Kvz/Buha "s" // Kal / Bb \\
9 & Giza 165 & Cmo / Mfd // Man "s". \\
10 & Sids 1 & HD 2171 / pavan "s" // 1158. 57 / rlaya 74 "s" \\
11 & Sids 3 & Sakha / Giza 155 \\
12 & Sids 4 & Maya "s" / Mon "s" // CMH 74 A. 59/5/Giza 157.z \\
13 & Gimmeiza 9 & ALD "s" / Huac "s" // CM 74A/ 6301 \\
14 & Sakha 92 & Napo 63 / Inia 66 // wern "s". \\
\hline
\end{tabular}

be used as testers to construct N. C. D. III population. A randomized complete block design with three replications was used. The genotypes were sown on $15^{\text {th }}$ of November 2002.

In 2003/2004 winter growing season, each of the twelve wheat genotypes were crossed to high performing parent (H. P) Gemmeiza 9 and low performing one (Lp)Sakha 92 to produce the $F_{1}$ seeds for $\mathrm{L}_{1 \mathrm{i}}(\mathrm{Hp} \times \mathrm{Gi})$ and $12 \mathrm{~L}_{2 \mathrm{i}}(\mathrm{Lp} \times \mathrm{Gi})$ respectively, where $\mathrm{Gi}=1$ to 12 the $\mathrm{F}_{1}$ grains of 24 families $\left(\mathrm{F} 1^{\mathrm{l} S}\right)$ with the parental genotypes were sown on $15^{\text {th }}$ November 2004. A randomized complete block design with three replications was used of row was $2 \mathrm{~m}$, row to row $20 \mathrm{~cm}$.and plant to plant spacing was $10 \mathrm{~cm}$,Number of rows for each $F_{1}$ and parental was 3 rows.Length Data recorded on $10 \mathrm{com}$ - petitive plants for each genotype in each replication. The studied characters were; heading date (days), plant height $(\mathrm{cm})$, flag leaf length $(\mathrm{cm})$, flag leaf width (cm), flag leaf area $\left(\mathrm{cm}^{2}\right)$, extrusion length $(\mathrm{cm})$, spike length $(\mathrm{cm})$, number of spikelets/spike, spike grain weight (g.), number of spikes/plant, number of grains/spike, 1000-grain weight and grain yield/plant (g.). The normal agricultural practices in wheat production were applied at the proper time during the abovementioned seasons

\section{Biometrical analysis}

Two-way analysis of variance of $\left(\mathrm{L}_{1 \mathrm{i}}\right.$ $\left.+\mathrm{L}_{2 \mathrm{i}}-\mathrm{p}_{\mathrm{i}}\right)$ and $\left(\mathrm{L}_{1 \mathrm{i}}+\mathrm{L}_{2 \mathrm{i}}\right)$ sets of families have been carried out for every character separately. The significancy $\mathrm{L}_{1 \mathrm{i}}+\mathrm{L}_{2 \mathrm{i}}-\mathrm{p}_{\mathrm{i}}$ 
MST to test epistasis, significancy $\mathrm{L}_{1 \mathrm{i}}+$ $\mathrm{L}_{2 \mathrm{i}}$ used to test of additive and $\mathrm{L}_{1 \mathrm{i}}+\mathrm{L}_{2 \mathrm{i}}$ used to test of dominance gene effects.

For test of epistasis twelve values of $\mathrm{L}_{1 \mathrm{i}}+\mathrm{L}_{2 \mathrm{i}} \mathrm{p}_{\mathrm{i}}, \mathrm{G}_{1}=1$ to 12 with degree of freedom was used to test of overall epistasis (Jinks and Virk 1977).

Detection and estimation of additive (D) and dominance $(\mathrm{H})$ and direction of dominance

Mean squares of $\mathrm{L}_{1 \mathrm{i}}+\mathrm{L}_{2 \mathrm{i}}$ (additive gene effects, $\mathrm{L}_{1 \mathrm{i}}+\mathrm{L}_{2 \mathrm{i}}$ (dominance gene effects) for 11 degrees of freedom were used. The estimation of $\mathrm{D}$ and $\mathrm{H}$, were obtained according to Comstock and Robinson (1952). The direction of dominance $(\mathrm{F})$ was computed from covariance of sums $\left(\mathrm{L}_{1 \mathrm{i}}+\mathrm{L}_{2 \mathrm{i}} /\right.$ differences $\left(\mathrm{L}_{1 \mathrm{i}}+\mathrm{L}_{2 \mathrm{i}}\right)$ which equal $1 / 8$.

The correlation coefficient of sums/differences was used to estimate the significancy of F-value (Jinks et al 1969).

\section{Genetic correlation}

The additive, dominance and epistasis genetic correlation were used to obtain 12 values for each of the studied character (Kearsey and Jinks, 1968; Jinks \& Perkins, 1970 and Kearsey et al 1987).

\section{Predicting the properties of recombi- nant lines}

The proportion of inbred superior or out perform parental range is equal to the probability integral corresponding to the value of $d / \sqrt{ } D$ while the range of inbred is given by $m \pm 2 / \sqrt{D}$ where $L_{1}-L_{2}=[d]$ and $\mathrm{m}=\mathrm{P}_{1}$. The proportion of recombinant lines corresponding to the probability level were obtained using Fisher and Yates Tables (1963).

\section{RESULTS AND DISCUSSION}

Mean squares of analysis of variance (Table 2) provide evidence for significant between families terms in all studied characters. These results might suggest that $\mathrm{L}_{1 \mathrm{i}}, \mathrm{L}_{2 \mathrm{i}}$ and $\mathrm{P}_{\mathrm{i}}$ families were significantly different from each other, revealing presence of fair amount of genetic variability which could be considered adequate for proceeding to further biometrical analysis by means of N.C.D. III.

\section{1- Test for epistasis}

Mean square for epistasis (Table 3) indicate significant overall epistasis in all studied characters except for number of spikes/plant In this respect Eissa (1994 a and b) and Al-Kaddoussi (1997) reported significant epistasis,but absence of epistasis was reported by Singh et al (1984) and Iqbal Singh et al (1989). Since epistasis played an important role in the inheritance of these characters,thus ignoring such effect one would not only lose information about epistasis, but also the estimates of additive and dominance components would be biased. For this reason the breeder should take epistasis into account in producing genetic models for studying quantitatively inherited characters.

\section{Detection and estimation of additive, dominance and direction of dominance}

Analysis of variance for sums $\left(\mathrm{L}_{1 \mathrm{i}}+\right.$ $\left.\mathrm{L}_{2 \mathrm{i}}\right)$ and differences $\left(\mathrm{L}_{1 \mathrm{i}}-\mathrm{L}_{2 \mathrm{i}}\right)$ indicated significant mean squares in all studied characters except for plant height and number of spikes/plant of sums $\left(\mathrm{L}_{1 \mathrm{i}}+\mathrm{L}_{2 \mathrm{i}}\right)$ and for plant height of differences $\left(\mathrm{L}_{1 \mathrm{i}}-\right.$ $\mathrm{L}_{2 \mathrm{i}}$ ). Significant mean squares for sums providing evidence for the presence of 
Arab Univ. J. Agric. Sci., 14(1), 2006 
additive gene effects in the genetic control for these characters. Similar results were obtained by Singh \& Singh (1976); Eissa (1994 a and b) and Al-Kaddoussi (1997). Significant of differences $\left(\mathrm{L}_{1 \mathrm{i}}\right.$ $\mathrm{L}_{2 \mathrm{i}}$ ) indicated that the dominance played the major role in the genetic control for these characters In this respect, Nanda et al (1983) and Al-Kaddoussi (1997).

Estimates of the genetic components of variations (Table 4) generally, indicated that the additive genetic components were larger in magnitude than the dominance ones for heading date, plant height, flag leaf length, flag leaf width, extrusion length, spike length and 1000- grain weight. But for the remaining characters the dominance genetic variance $(\mathrm{H})$ was larger than the additive (D) resulting in $(\mathrm{H} / \mathrm{D})^{0.5}$ more than one confirming the role of over dominance gene effects in the genetic control for these characters. The (F) value was not significant for studied characters, revealing that dominance was ambidirectional. The estimation of additive and dominance genetic components were biased by epistasis to unknown extent as a result of which to no precise conclusion can be drawn about the relative importance of these components. The absence of epistasis for number of spikes/plant may suggest that additive and dominance genetic components was unambiguous. The value $(\mathrm{H} / \mathrm{D})^{0.5}>1$ for these character suggest that, until hybrid vigor in wheat becomes more feasible the population improvement through pedigree method or triple test cross would be of great response (Jensen, 1970).

\section{Predicting the properties of recombi- nant lines}

The information obtained from the (N.C.D.) families was used to predict the likely proportion of recombinant lines that could be derived from selfing the $\mathrm{F}_{2}$ progeny of cross between parents. N. C. D III may be considered as useful source for such information to make prediction (Jinks \& Pooni 1976 and Pooni \& Jinks 1978). Prediction results given. in Table (5) revealed that best predictable inbred line $(\mathrm{P} \max )$ and having alleles for the desired traits and exceeding of $F_{1}$ hybrid were obtained for heading date, flag leaf length, flag leaf width, spike length, number of spikelets/spike, number of grains/spike, 1000- grain weight and grain yield/plant. Similar results were reported by Eissa (1994c) and AlKaddoussi (1997).

The conventional breeding methods are of labour and time consuming to overcome to predict the potential of recombinant lines that could be derived by number of selfing generations of a cross between two inbred lines. They used the normal probability integral equation ([d] $/ \sqrt{ }$ ) to predict the proportion of inbred falling out side parental range of a cross. The results of prediction provide evidence that the highest proportion of recombinant lines were obtained for heading date (38.97), flag leaf length (37.82), flag leaf width (44.43), number of spikelets/spike (43.64), number of grains/spike (39.74), 1000- grain weight (41.29) and grain yield/plant (47.21) indicating that these characters are promising ones and give the breeder courage to consider these parents and crosses in a breeding programme aiming to improve these characters. In this respect, high proportion of recombinant inbreds likely to fall out side parent range were obtained for spike length (Al-Kaddoussi and Eissa 1990) and grain weight/spike (Eissa 1994c and Al-Kaddoussi 1997). 
Salama; Awaad and Salem

Arab Univ. J. Agric. Sci., 14(1), 2006 
Salama; Awaad and Salem

Arab Univ. J. Agric. Sci., 14(1), 2006 
Arab Univ. J. Agric. Sci., 14(1), 2006 
Salama; Awaad and Salem

Arab Univ. J. Agric. Sci., 14(1), 2006 


\section{Genetic correlation}

The kind of relationship which accur between characters is important for better planning of a selection programme. The knowledge of phenotypic and genetic correlation help the breeder to improve the efficiency of selection by using favorable combination of characters and to minimize the retarding effect of those characters It is possible to increase the efficiency of selection for one character by indirect selection via another character.

Separation out the genetic correlation to its components of epistasis, additive and dominance genetic correlations computed the epistasis genetic correlation. Table (6) provides evidence for positive and significant genetic correlation between epistatic gene effects controlling heading date and each of plant height, flag leaf length and flag leaf width; between plant height and each of extrusion length, number of spikelets/spike, spike grain weight, number of spikes/plant and number of grains/spike, between flag leaf width and each of, flag leaf area, spike grain weight and 1000- grain weight, between spike length and number of spikelets/spike, between number of spikelets/spike, and each of number of grains/spike and grain yield/plant, between grain yield/plant and each of, number of spikes/plant, number of grains/ spike and 1000- grain weight.

The additive genetic correlation results (Table 7) indicate positive and significant correlation between heading date and each of, flag leaf area and 1000grain weight; between spike length and number of spikelets/spike and between grain yield/plant and each of; spike grain weight, number spikes/plant, number of grains/spike and 1000- grain weight.

The dominance genetic correlation shown in Table (8) indicate that, positive and significant correlation between heading date and grain yield/plant, between each of flag leaf length, spike length and grain yield/plant, between grain yield/plant and each of: spike length, number of spikelets/spike, spike grain weight, number of spikes/plant, number of grains/spike and 1000- grain weight generally the results revealed that both additive and dominance gene effects controlling yield and its contributing characters (number of spikes/plant, number of grains/spike, 1000-grain weight) were significantly correlated with each other, suggesting a common genetic pool, or pleiotropy. Since additive effect of genes is a fixable type, therefore, correlation between additive genes is favorable. Thus, selection based on such type may indicate that the indirect selection via number of grains/spike or grain weight/spike would be effective in improving grain yield and reinforcing its importance as a selection criteria.

\section{REFERNCES}

Al-Kaddoussi (1997). Testing for epistasis, prediction and genetic correlation using North Carolina Design III biometrical approach for Egyptian bread wheat (Tricticum aestivum, L.). Zagazig J. Agric, Res. 24: 37-50.

Al-Kaddoussi A.R. and M.M. Eissa (1990). Gene action and prediction of some yield attributes in four wheat crosses (Triticum aestivum, L.). Annals of Agric. Sci. Moshtohor 28:2013-2023. Comstock, R.E. and H.F. Robinson (1952). Estimation of Average Domi- 
nance of Genes. Heterosis, Chap. 30. Iowa State College Press, Ames, Iowa, USA.

Eissa, M.M. (1994a). Triple test cross analysis in bread wheat (Triticum aestivum,L.). Zagazig J. Agric. Res. 21 : 110.

Eissa, M.M. (1994 b). Detect epistasis for yield and its test cross analysis (Triticum aestivum,L.). Zagazig J. Agric. Res. $21: 11-21$.

Eissa, M.M. (1994c). Genetic correlation and predicting new recombinant lines in bread wheat using triple test cross analysis. Zagazig J. Agric. Res. 21: 21-31.

Fisher, R.A. and F. Yates (1963). Statistical Tables for Biological Agricultural and Medical Research. Oliver and Boyd. Edinburgh.

Iqbal Singh; I.S. Pawar and S. Singh (1989). Detection of genotype $\times$ environment interaction in spring wheat through triple test cross analysis. Crop Improvements, 16: 34-37.

Jensen, N.F. (1970). A diallel selective mating system of cereal breeding. Crop Sci., 10: 629-635.

Jinks, J.L. and J.M. Perkins (1970). A general method for the detection of additive, dominance and epistatic components of variation II. $\mathrm{F}_{2}$ and back cross populations. Heredity 25 : 419-429.

Jinks, J.L. and H.S. Pooni (1976). Predicting the properties of recombinant lines derived by single seed descent. $\boldsymbol{H e}$ redity, 36 : 253-266.

Jinks, J.L. and D.S. Virk (1977). A modified triple test analysis to test and allow for inadequate testers. Heredity, 38: 165-170.

Jinks, J.L.; J.M. Perkins, and E.L. Brecese (1969). A general method of detecting additive, dominance and epistatic variation for metrical traits: II. Ap- plication to inbred lines. Heredity 24 : 45-57.

Katiyar, P.K. and A. Ziauddin (1996). Detection of epistasis components over two environments in bread wheat. Indian J. Genet. 56 : 285-291.

Kearsey, M.J. and J.I. Jinks (1968). A general method of detecting additive, dominance and epistatie variation for metrical traits. Heredity, 23 : 403-409.

Kearsey, M.J.; M.D. Hayward; F.D. Devey; S. Arcionic, M.P. Eggleston and M.M. Eissa (1987). Genetical analysis of production characters in Lolium. i. Triple test cross analysis of spaced plant performance. Theor. Appl. Genet.75: 66-75. Nanda, G.S.; Singh and K.S. Gill (1983). Estimating epistasis through triple test cross in wheat Indian. J. Genet, 43: 160-163.

Nanda G.S.; G. Singh and K. Chand (1990). Detection of a components of genetic variation and prediction of the frequencies of trangressive segregates in bread wheat (Triticum aestivum L.). J. of Genetics and Breeding, 44 : 63-66.

Pawar, I.S.; M. Yunus; S. Singh and V.P. Singh (1994). Detection of additive, dominance and epistatic variation in wheat using triple test cross method. Indian J. of Genet. and Plant Breeding, 54: 275-280.

Pooni, H.S. and J.L. Jinks (1978). Predicting the properties of recombinant inbred lines derived by single seed descent for two or more characters simultaneously. Heredity, 40 : 349-361.

Salama S.M. (1998). Breeding Studies on Wheat, pp. 42-103. Ph.D. Thesis. Agron. Department, Fac. of Agric, Zagazig University, Egypt.

Salama S.M. (2000a). Diallel analysis for yield and its components in bread 
wheat (Triticum aestivum,L). Egypt J. Appl. Sci, 15: 77-89.

Salama S.M. (2000b). Partial diallel analysis and heterosis in bread wheat (Triticum aestivum, L.). Zagazig J. Agric. Res. 27 : 1371-1384.

Salama, S.M. (2002). Genetic analysis of yield and some yield attributes in some Egyptian wheat cultivars. Zagazig. J. Agric Res. 29: 1395-1410.

Singh, G. (1989). Estimation of gene a action through triple test cross in bread wheat. Indian J. of Agric. Sci 59: 700-
Singh, S. and R.B. Singh (1976). Triple test cross analysis in two wheat crosses. Heredity, 37: 173-177. Singh, S,; M. Yunus and R.S. Paroda (1984). Detection of epistasis in a cross of bread wheat. Indian J. Agric. Sci. 54 : 250-252.

Singh, I.; I.S. Pawar and R.B. Singh (1988). Detection of additive, dominance and epistatic components of genetic variation for some metric traits in wheat. Genetica Agraria 42 : 371-378. 702 .

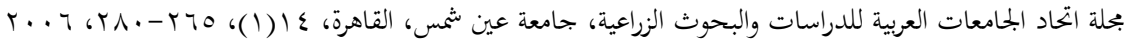

\title{
تقدير المكونات الوراثية والتتبؤ والارتباط الوراثي في قمح الخبز باستخدام النموذج الثالث للنورث كارولينا
}

\author{
سليمان محمد جمعة سلامة' - سعيد السيد عواد' - منال مصطفى سالم' \\ 1 - المعمل المركزي لبحوث التصميم والتحليل الإحصائي - مركز البحوث الزراعية - الجيزة - مصر فيلال
}

كلاً منهم رجعياً مع الصنفين جميزة 9 الأعلى

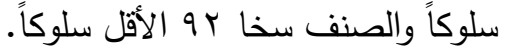
وتم دراسة الصفات التالية

ميعاد طرد السنابل باليوم وارتفاع النبات

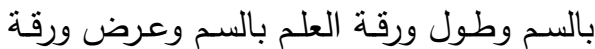

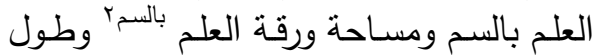

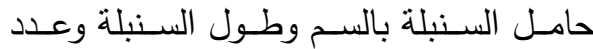

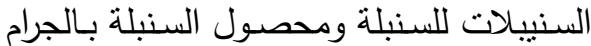
وعدد السـنابل للنبـات وعدد حبـوب السـنبلة ووزن الألكف حبـة بـالجرام ومحصـول النبـات الفردي بالجرام المبن ولقد أظهرت النتائج الآتي
أجـرى هـذا البحـث فـي الموسـم الثـتوبي

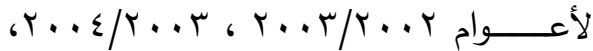

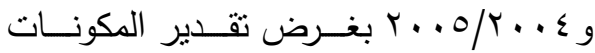

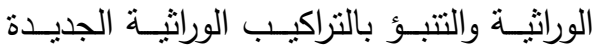
وحساب الارتباط الوراثي بين جينات التفاعل التراكل غير الآليلي وكذلك الجينات الدضيفة والسائدة وذلك باسـتخدام النمـوذج الإحســائي الـوراثي

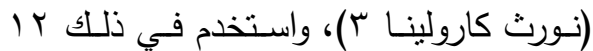
تركيب وراثي من قمتح الخبز وهي سخا

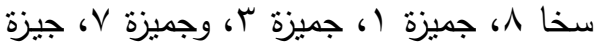

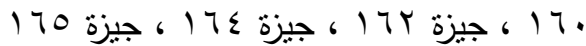
، سدس ( ، سدس ب ، وسدس ع وتم تهجين 
0- تشير النتائج انه يمكن الحصول على التى

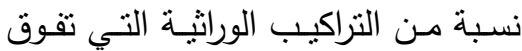

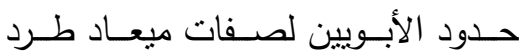

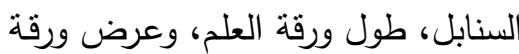

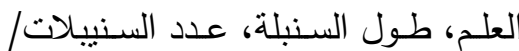
سنبلة، وعدد السنابل، ووزن الألف حبة، ومحصول الحبوب للنبات.

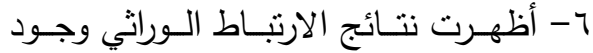
ارتبـاط بين جينـات التفاعل الغير آليلي وكذللك الجينـات المضـيفة والسـائدة التي التي تحكـم صـفات محصــول السـنبلة وعـدند السنابل/ نبات وعدد الحبوب للسنبلة ووزن الألف حبـة مـع محصول النبات الفردي.

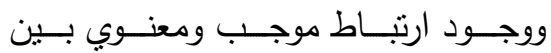

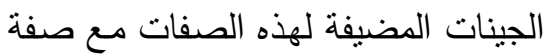

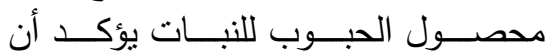

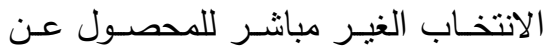
طريـق هذه الصـفات ذات فاعليـة عاليـة ويمكن استخدامها كأدلة انتخابية لتحسين المحصول في القـح.
1- كان للتفاعل الغير آليلي دوراً هاماً في

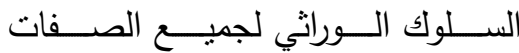

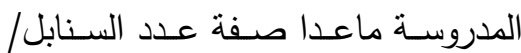

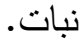

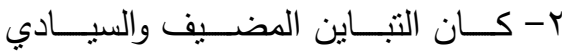

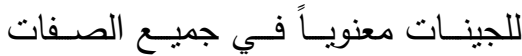

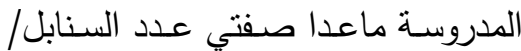
نبات وعدد حبوب السنبلة. r- أظهرت النسبة بين التباين السيادي إلى

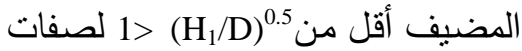

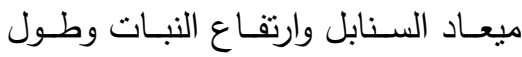
ورقـة العلم وعـرض ورقـة العلـم وطول وطـل

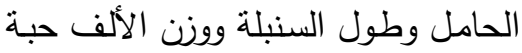
مما يوضـح أهميـة التباين الراجع للفعل الفيل

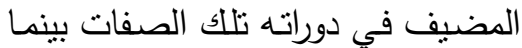

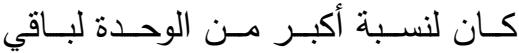
الصفات المدروسة.

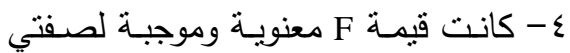
طول ورقة العلم ومساحة ورقة العلم مما كاديا

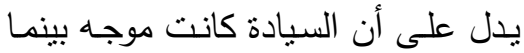

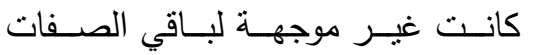
المدروسة.

تحكيم: 1.د عبدالمقصود محروس المراكبى

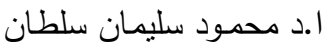

